\title{
Sociodemographic Data and the Relationship with the Climacteric Symptomatology - Paraiba, Northeast of Brazil
}

Maria do Carmo Andrade Duarte de Farias ${ }^{1}$, Renan Alves Silva², Marina Mendes Luiz ${ }^{3}$, Rosimery Cruz de Oliveira Dantas ${ }^{3}$, Eliane de Sousa Leite ${ }^{3}$, Kévia Katiúcia Santos Bezerra1, Anne Milane Formiga Bezerra ${ }^{4}$, Platiny Benício Calou ${ }^{5}$, Helen Melo Oliveira ${ }^{5}$, Danielly Hallany de Bessa Cavalcante ${ }^{5}$, Kennia Sibelly Marques de Abrantes ${ }^{3,6}$, Luiz Carlos de Abreu ${ }^{6}$

\section{Abstract}

Introduction: The climacteric is a natural phenomenon of the female physiology, experienced as a silent period or followed by symptoms.

Objectives: Identifying sociodemographic data and their influence on climacteric change; determining the prevalence of climacteric symptoms.

Method: A cross-sectional study conducted in the city of Cajazeiras, Paraíba, between January 2013 and March 2014, interviewing 390 climacteric women, through structured script. The factors associated with climacteric symptoms were identified by linear regression analysis (95\%).

Results: The average age of the surveyed was 49.17 years old. The intensity of climacteric symptoms was associated to: the menopausal age ( $p=0.048, \mathrm{Cl}$ : 0.001 to 0.149$)$ and education $(p=0.003, \mathrm{Cl}$ : -0.254 to -0.051 ); being the most prevalent: $84.4 \%$ nervousness, arthralgia $78.2 \%$ and $76.4 \%$ sadness.

Conclusion: Due to insufficient socioeconomic status and the high prevalence of menopausal symptoms, we see the need for qualified and humanized care through a comprehensive and individualized care in order to improve the women's quality of life.
1 Academic Unit of Life Sciences, Teacher training center, Federal University of Campina Grande. Cajazeiras, Paraíba, Brazil.

2 Graduate-degree in Nursing, Federal University of Ceará. Fortaleza, Ceará, Brazil.

3 Academic Unit of Nursing, Teacher training center, Federal University of Campina Grande. Cajazeiras, Paraíba, Brazil.

4 Nurse in a Mobile Emergency Service, MSU, Sousa, PB, Brazil.

5 Student of Medicine, Academic Unit of Life Sciences, Federal University of Campina Grande. Cajazeiras, Paraíba, Brazil.

6 Scientific Writing Laboratories, Faculty of Medicine of ABC, Santo Andre, SP, Brazil.

\section{Contact information:}

Maria do Carmo Andrade Duarte de Farias.

Academic Unit of Life Sciences, Teacher training center, Federal University of Campina Grande.

Address: Federal University of Campina Grande. Rua Sérgio Moreira de Figueiredo, sn Bairro Casas Populares, Cajazeiras, PB CEP 58900-000.

झ carmo.andrade@ufcg.edu.br 


\section{Introduction}

Menopause is a natural and inevitable phenomenon of female physiology, sometimes experienced as a silent period; other may be accompanied by symptoms that affect the lives of women. It is defined by the World Health Organization (WHO) as a biological and non-pathological stage, which comprises the transition from the reproductive stage to the non-reproductive, menopause is considered a hallmark of this phase, which is the last menstrual cycle, only confirmed after 12 months of its occurrence, happening, usually around the age of 50 [1-2].

According to the Ministry of Health, the age limit for menopause matches from 35 to 65 years of age. DATASUS estimates that in 2007, the Brazilian female population totaled more than $98 \mathrm{mi}-$ Ilion women, in which about 30 million, comprising $32 \%$ of women in Brazil, were framed in the age group that is the climaterium [1]. According to the Brazilian Institute of Geography and Statistics (IBGE), in Brazil in 2010 the total population in the age group 35-64 years old was 63.657.039 (33.099.418 women, 52\%) being 15.939.984 $(8.374 .752,52.5 \%)$ in the Northeast and Paraíba 1.167 .275 (619431, 53\%) in João Pessoa 245.893 $(135.759,52.2 \%)[3]$

In 2013, according to the IBGE, the life expectancy for Brazilian women, considering all races, is around 78.6 years old [4], remaining women a third of their lives over 50 years old, meaning that after menopause has long useful life to be used [5].

In this sense, there is agreement that the comprehensive health care to women implies the assistance at all stages of his life, noting that the climacteric, involves a relatively long period of life of women, and should be given increased attention of society. It is therefore necessary, during and after menopause, the adoption of measures that show the search of a better quality of life, so that women can experience this phase smoothly [6].
During climacterium, there may be a variety of changes, including physical and psychological, especially hot flashes, sleep disturbance, sadness, emotional instability, changes in sexual habits and skin, which are usually associated with personal experiences with negative impact on health and women's quality of life [7].

The objectives are to identifying sociodemographic data related to the climacteric symptoms; assess the prevalence of climacteric symptoms in women in the hinterland of Paraíba, Northeast of Brazil.

\section{Method}

This is a prospective cross-sectional study conducted in the city of Cajazeiras - Paraiba, in the Urban Zone, from January 2013 to March 2014. The sample consisted of 427 women, and 390 completed the protocol. The collection of data passed in fourteen health units in the urban area of the municipality of Cajazeiras-PB.

As inclusion criteria were women aged between 35 and 65 years old and those agreed to participate by signing the Informed Consent (IC). Exclusion criteria were: hysterectomized women in hormonal or users of hormonal contraceptives therapy, considering that such facts can interfere with the symptoms of menopause; and absence of climacteric symptoms. This research project was approved by the Research Ethics Committee of the State University of Paraíba, Campina Grande (PB), and CAAE: 0462.0.133.000-11.

In order to implement the data collection took place the interview technique, using a structured questionnaire, covering items to characterize the sociodemographic profile and check the intensity of climacteric symptoms.

The intensity of climacteric symptoms was assessed quantitatively by quantitatively by BlattKupperman Menopausal Index (BKMI). In this Index are considered the following symptoms: hot 
flashes, paraesthesia, sleep disorder, nervousness, sadness/melancholy, dizziness, tiredness, arthralgia/myalgia, headache, palpitations and tingling, being assigned a value to each symptom, varying with the intensity of the same [8].

To determine the BKMI the various symptoms are rated according to their intensity, being cataloged as mild, moderate and severe (Frame 1). Thus, vasomotor symptoms, according to the intensity of received values 4, 8 and 12; paresthesia, sleep disturbance, and nervousness 2, 4 and 6; while sadness/melancholy, dizziness, weakness, arthralgia/ myalgia, hea-

Frame 1. Evalution of climacteric symptomatology: Blatt-Kupperman Menopausal Index [8].

\begin{tabular}{|c|c|c|c|c|}
\hline Symptoms & Low & Moderate & High & Score \\
\hline \multirow[t]{2}{*}{ Hot flashes } & 4 & 8 & 12 & \\
\hline & (1-3/day) & (4-8/day) & (> 10/day) & \\
\hline Paresthesia & 2 & 4 & 6 & \\
\hline $\begin{array}{l}\text { Sleep } \\
\text { disorder }\end{array}$ & 2 & 4 & 6 & \\
\hline Nervousness & 2 & 4 & 6 & \\
\hline $\begin{array}{l}\text { Sadness/ } \\
\text { Melancholy }\end{array}$ & 1 & 2 & 3 & \\
\hline Vertigo & 1 & 2 & 3 & \\
\hline Tiredness & 1 & 2 & 3 & \\
\hline $\begin{array}{l}\text { Arthralgia/ } \\
\text { Myalgia }\end{array}$ & 1 & 2 & 3 & \\
\hline Headache & 1 & 2 & 3 & \\
\hline Palpitation & 1 & 2 & 3 & \\
\hline Tingling & 1 & 2 & 3 & \\
\hline Total & & & & \\
\hline
\end{tabular}

dache, palpitations and tingling, the values 1, 2 and 3. Thereafter, these values were summed and the estimated index as follows: light, up to 19 points; moderate, 20 to 35 points and sharp, greater than 35 points [8].

In the processing of the data there was used the Statistical Package for Social Sciences - SPSS, version 17. For analysis it was used descriptive statistics, having as measure of central tendency the average. And the application of the chi-square test $\left(x^{2}\right)$, observing the values of the standard deviation (SD) and confidence interval $(\mathrm{Cl})$ in order to obtain the correlation between the variables. To confirm the relation between the variables we applied the linear regression model.

In the variables age, education and BKMI identified the minimum and maximum value, the mean and standard deviation; In the correlation between variables we used the Simple Linear Regression; adopting Confidence Interval $(\mathrm{Cl})$ of $95 \%$ and a significance level of $5 \%(p<0.05)$ to reject the null hypothesis, and the BKMI the dependent variable. In the description of sociodemographic variables and the prevalence of symptoms data were presented in tables with frequency and percentage; and discussed based on the literature on the subject in focus.

\section{Results}

The data shown in Table 1 reveal that the average age of women in years was 49.2 years old $( \pm 7.9$ years), which suggests that women are experiencing menopausal symptoms from 41.3 years old and

Table 1. Characterization of climacteric women's, regarding menopausal age, schooling and Blatt-Kupperman Menopausal Index. Cajazeiras-PB, 2013-2014.

\begin{tabular}{|l|c|c|c|c|c|}
\hline \multicolumn{1}{|c|}{ Variables } & Total & Minimum value & Maximum value & Average & SD \\
\hline Age (in years) & 390 & 35 & 65 & 49.2 & 7.9 \\
\hline Schooling (in years) & 390 & 0 & 22 & 7.7 & 4.8 \\
\hline BKMI (Score) & 390 & 1 & 47 & 21.9 & 10.3 \\
\hline
\end{tabular}


with a maximum age of 57.1 years old. The average years of schooling was 7.7 years ( \pm 4.8 years). Regarding the BKMI the sample had an average score of $21.9( \pm 10.3)$.

Table 2 shows that in this sample the majority of women was found in extremes of age, or $35.7 \%$ were premenopausal $(n=139)$ and $41 \%$ in postmenopausal women $(n=160)$. Most had a steady partner 68.2\% ( $n=266), 54.4 \%$ were white $(n=212)$, with level of study between 6 and 11 years, 42.3\% ( $n=165)$. Occupation had paid $52,8 \%(n=206)$, with a per capita income < 1 minimum wage, $74.7 \%(n=292)$. Most women menopausal symptoms showed moderate $49 \%$ ( $n$ = 191). With the exception of pre-menopausal, in all subcategories of variables the average BKMI reveals moderate symptoms. In the correlation between variables and the BKMI it was realized that schooling interfere with the intensity of symptoms ( $p=0.028$ ).

Given the possibility of interference of confounding variables in the previous analysis, we proceeded to the linear regression, with the outcome variable the climacteric symptoms (BKMI). The data demonstrated that only the variables menopausal age $(a=0.048)$ and education $(a=0.003)$ had a direct relationship with the BKMI. Thus, it was confirmed that the increase in reducing age and years of education were significantly associated with the most intense climacteric symptoms. This implies that each year plus the woman's age increases by 0.175 score of climacteric symptoms, and for the education variable, linear regression reveals that each year of study added in woman's education decreases the score of 0.321 BKMI (Table 3 ).

In relation to $m$ enopausal symptoms, we observed that, in descending order, the most prevalent symptoms were nervousness $84.4 \%(n=329)$, arthralgia $78.2 \%$ ( $n=305)$, sadness/melancholy $76.4 \%(n=298)$, tiredness $74.4 \%(n=290)$, headache $71.8 \%(n=280)$. The dissatisfaction with sleep
Table 2. Descriptive analysis of the social and demographic data of the climacteric womens of the municipality of Cajazeiras -PB, 2013-2014.

\begin{tabular}{|c|c|c|c|c|}
\hline Variables & $f$ & $\%$ & $\begin{array}{c}\text { BKMI } \\
\text { Average (SD) }\end{array}$ & $\mathbf{p}$ \\
\hline \multicolumn{5}{|l|}{ Age (years) } \\
\hline $\begin{array}{l}\text { pre-menopause } \\
\text { - } 35-45\end{array}$ & 139 & 35.7 & $19.9(10.3)$ & \multirow[t]{3}{*}{0.153} \\
\hline $\begin{array}{l}\text { perimenopause } \\
-46 \text { - } 51\end{array}$ & 91 & 23.3 & $22(10.8)$ & \\
\hline $\begin{array}{l}\text { post-menopause } \\
-52-65\end{array}$ & 160 & 41.0 & $22.7(9.7)$ & \\
\hline \multicolumn{5}{|l|}{ Marital Status } \\
\hline With a partner & 266 & 68.2 & $22.3(10.1)$ & \multirow[t]{2}{*}{0.496} \\
\hline Without a partner & 124 & 31.8 & $21(10.8)$ & \\
\hline \multicolumn{5}{|l|}{ Skin color } \\
\hline White & 212 & 54.4 & $22.3(10.6)$ & \multirow[t]{2}{*}{0.245} \\
\hline Non white & 178 & 45.6 & $21.5(10)$ & \\
\hline \multicolumn{5}{|l|}{ Schooling (in years) } \\
\hline $0-5$ & 158 & 40.5 & $23.5(10.8)$ & \multirow[t]{3}{*}{$0.028 *$} \\
\hline $6-11$ & 165 & 42.3 & $21.5(9.9)$ & \\
\hline 12 or older & 67 & 17.2 & $19.4(9.4)$ & \\
\hline \multicolumn{5}{|l|}{ Financial Situation } \\
\hline Remunerated & 206 & 52.8 & $21.4(10)$ & \multirow[t]{2}{*}{0.199} \\
\hline Unpaid & 184 & 47.2 & $22.5(10.6)$ & \\
\hline \multicolumn{5}{|l|}{ Per capita income } \\
\hline $0,1-0,9$ & 292 & 74.7 & $21.6(10.3)$ & \multirow[t]{3}{*}{0.664} \\
\hline $1-1,5$ & 69 & 17.8 & $24.1(9.8)$ & \\
\hline over 1,5 & 29 & 7.5 & $20(11)$ & \\
\hline \multicolumn{5}{|l|}{ Work place } \\
\hline At home & 220 & 56.4 & $22.5(10.5)$ & \multirow[t]{2}{*}{0.194} \\
\hline Outside the home & 170 & 43.6 & $21(10)$ & \\
\hline \multicolumn{5}{|l|}{ BKMI } \\
\hline low -1 to 19 & 157 & 40.2 & $11.7(5.0)$ & \\
\hline moderate - 20 to 35 & 191 & 49 & $26.4(4.1)$ & \\
\hline high - > 35 & 42 & 10.8 & $39.9(3.0)$ & \\
\hline \multicolumn{2}{|c|}{$\begin{array}{l}\text { * Statistical significance Test } \\
x^{2} p<0.05\end{array}$} & \multicolumn{3}{|c|}{ Source: Research data. } \\
\hline
\end{tabular}


Table 3. Linear regression model of socio-demographic variables correlated with the Blatt-Kupperman Menopausal Index. Cajazeiras-PB, 2013-2014.

\begin{tabular}{|c|c|c|c|c|c|}
\hline \multirow{2}{*}{$\begin{array}{l}\text { Socio-demographic } \\
\text { variables }\end{array}$} & \multirow{2}{*}{$\beta_{0}$} & \multirow{2}{*}{$\beta_{1}$} & \multirow{2}{*}{$\mathbf{P}$} & \multicolumn{2}{|c|}{ Confidence Interval (CI) 95\% } \\
\hline & & & & Minimum & Maximum \\
\hline Menopausal age & 0.075 & 0.100 & 0.048 & 0.001 & 0.149 \\
\hline Schooling & -0.152 & -0.169 & 0.003 & -0.254 & -0.051 \\
\hline Per capita income & 0.101 & 0.095 & 0.095 & -0.018 & 0.220 \\
\hline Dependent variable: BKM & \multicolumn{5}{|c|}{ Source: Research data. } \\
\hline
\end{tabular}

was evident in this study, being reported by $67.2 \%$ $(n=262)$ of women. It was found that the less prevalent paresthesia symptom was $61.3 \%(n=239)$; and that the hot flush, indicated in common sense as the main feature of menopause was reported by $64.1 \%(n=250)$ women (Table 4). It is noteworthy that each woman interviewed complained of one or more symptom.

Table 4. The prevalence of climacteric symptoms. Cajazeiras-PB, 2013-2014 ( $n=390)$.

\begin{tabular}{|l|c|}
\hline \multicolumn{1}{|c|}{ Symptoms } & Present \\
\hline Nervousness & $84.4(329)$ \\
\hline Arthralgia & $78.2(305)$ \\
\hline Sadness/Melancholy & $76.4(298)$ \\
\hline Tiredness & $74.4(290)$ \\
\hline Headache & $71.8(280)$ \\
\hline Sleep disorder & $67.2(262)$ \\
\hline Vertigo & $64.9(253)$ \\
\hline Hot flushes & $64.1(250)$ \\
\hline Palpitation & $62.8(245)$ \\
\hline Paresthesia & $61.3(239)$ \\
\hline Source: Research data & \\
\hline
\end{tabular}


The independence of the symptoms and the workplace was characteristic found in the sample (Table 2 and 3). However, it is assumed that the woman who owns professional activity outside the home, through contact with other women, can exchange experiences, universalizing their doubts, feelings and symptoms, reducing anxiety levels [12].

In the composition of the evaluation of the scale BKMI deserves attention the prevalence of nervousness, headache and sadness/melancholy among women surveyed (Table 4). During menopause there is a greater tendency to sadness/melancholy, often attributed to fear of aging, the perception of approaching death, feelings of worthlessness and lack of affection. This phase is also marked by a physical and social transition, going along with the independence of children, death of family and retirement, which require difficult emotional adaptations to the woman [13].

The neuropsychic symptoms can be influenced by lifestyle, professional activity, exercise and diet, in addition to the socio-cultural context in which the woman is inserted. It has also been pointed out that Brazilian women can show a negative perception on the stage of menopause, since, in the country, aesthetics and cheerfulness are highly valued, affecting the emotional reaction of women during this phase [14].

Add to this the fact that hypoestrogenism can reduce the secretion of brain endorphins, favoring the emergence of depressive symptoms, cognitive difficulties and even dementia processes. In addition, emotional lability after menopause is also related to the severity of hot flashes, which can interfere with sleep, causing irritability and difficulties in social interaction [10].

Somatic symptoms and preferred emotional difficulties investigated by women are justified, because in the years following menopause, there are the hot flashes or hot flushes, which interfere with the women's quality of life; and seem to be produced by alterations in the hypothalamic thermoregulatory system, leading to peripheral vasomotor instability of characteristic behavioral changes [15-16].

With regard to the prevalence of sleep disorders in this study (Table 4), it is known that after menopause, the difficulty with sleep, in contrast to other climacteric complaints appear to become more intense. However, although we did not see a decisive relationship between sleep disturbances and variations of steroids and could be related to the severity of vasomotor symptoms or to mental disorders, although there is a more intimate association between sleep disturbance and heat waves [17-18].

In a study with 50 women between the age group 45-59 years old, it was realized that the problems associated with anxiety, depression, attention deficit and changes in sleep patterns were very uncomfortable and distressing. However, studies are still restricted on the factors that interfere with sleep patterns in women after menopause and its possible consequences on quality of life [19-20].

Research conducted with 30 women going through the menopause period revealed that 53.3\% indicated irritated more easily than they used to, $20 \%$ had difficulty making decisions and 16\% reported problems with sleep [21].

\section{Conclusions}

This research denies the hypothesis that women with lower financial condition have higher intensity of climacteric symptoms. However, demonstrated that the intensity of the symptoms reported by the interviewed women increases as we age and decreases with the increase in years of schooling; and that the main symptoms that affect women in the climacteric period were nervousness $84.5 \%$, and arthralgia $78.6 \%$, sadness/ melancholy $76.2 \%$. 
However, the unfavorable demographic conditions and the high prevalence of symptoms confirm that menopause has a strong impact on women's lives; and which shall be proportionate to the woman several possibilities of intervention at this stage of life.

Therefore, it is essential that it has space to express their problems and feelings; receiving guidance on the changes taking place in their body; and what these can cause to their health.

Thus, we see the need for a more qualified and humanized assistance to this population, through a comprehensive and individualized care, aiming at a better quality of life.

The results of this research, a pioneer in the investigated reality, will help not only the planning of services and care routines, as may also direct teaching in the relevant institutions and, above all, to justify the need for more extensive research, including physiological variables, like estrogen levels, calcium, lipids, among others, based on the regional diversity of the Brazilian reality.

\section{References}

1. Ministério da Saúde (BR). Climatério. Available from: $\underline{\text { http:// }}$ portal.saude.gov.br/portal/saude/default.cfm

2. Leite ES, Oliveira FB, Martins ÁKL, Ramalho KKA, Torquato JA. Perspectives on women climacteric: concepts and impacts on health basic care. R. pesq.: cuid. fundam. Online, 2012 Oct-Dec; 4(4): 2942-52. Available from: http://www.seer.unirio. br/index.php/cuidadofundamental/article/view/1850/pdf 636\#. doi: 10.9789/2175-5361

3. Ministério da Saúde. População por Unidade da Federação segundo Região, Estado e Capital. Faixa Etária: 35 a 39 anos, 40 a 44 anos, 45 a 49 anos, 50 a 54 anos, 55 a 59 anos, 60 a 64 anos. Período: 2010. Available from: http://tabnet.datasus.gov. br/cgi/tabcgi.exe?idb2011/a01.def

4. Instituto Brasileiro de Geografia e Estatística. Expectativa de vida ao nascer, 2013. Available from: http://saladeimprensa.ibge.gov.

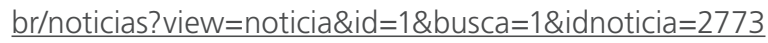

5. Ministério da Saúde (BR). Secretaria de Atenção à Saúde. Manual de Atenção à Mulher no Climatério/Menopausa. Brasília: Ministério da Saúde; 2008.

6. Pedro AO, Pinto-Neto AM, Costa-Paiva LHS, Osis MJD, Hardy EE. Procura de serviço médico por mulheres climatéricas brasileiras. Rev Saúde Pública. 2002; 36(4): 484-90. doi: 10.1590/S003489102013000100001

7. Freitas KM, Silva ARV, Silva RM. Mulheres vivenciando o Climatério. Acta Scientiarum Health Sciences. Maringá 2004; 26(1): 121-8. doi: 10.4025.

8. Wender COM, Freitas F, De Castro JAS, Vanin C. Climatério. In: Freitas F, Menke CH, Rivoire WA, Passos EP. Rotinas em ginecologia. Porto Alegre: Artmed; 2011. P. p. 542-60.

9. Pedro AO, Pinto-Neto AM, Costa-Paiva LHS, Osis MJD, Hardy EE. Idade de ocorrência da menopausa natural em mulheres brasileiras: resultados de um inquérito populacional domiciliar. Cad Saúde Pública. Rio de Janeiro, 2003 Jan-Fev; 19(1): 17-25. doi: 10.1590/0102-311XED010813.

10. De Lorenzi DRS, Baracat EC, Saciloto B, Padilha JR I. Fatores associados à qualidade de vida após a menopausa. Rev Assoc Med Bras. 2006; 52(5):312-7. doi: 10.1590/S010442302003000100043.

11. De Lorenzi DRS, Basso E, Fagundes PO, Saciloto B. Prevalência de sobrepeso e obesidade no Climatério. Rev Bras Ginecol Obstet. 2005; 27(8): 479-84. doi: 10.1590/S010072032003000900005 .

12. De Lorenzi DRS, Saciloto B, Ártico GR, Fontana SKR. Qualidade de vida e fatores associados em mulheres climatéricas residentes na região sul do Brasil. Acta Med Port. 2009; 22(1): 51-58. doi: 10.1056 .

13. Silva RM, Araújo $C B$, Silva ARV. Alterações biopsicossociais da mulher no Climatério. RBPS. 2003; 16(1/2): 28-33. doi: 10.5020/18061230.2003.p28 


\section{INTERNATIONAL ARCHIVES OF MEDICINE

14. Melo NR, Pompei LM, Machado RB, Fernandes CE. Climatério e menopausa. In: Lopes AC. Tratado de clínica médica. v.2. São Paulo: Roca; 2006. p. 3525-31.

15. De Lorenzi DRS, Catan LB, Moreira K, Ártico GR Assistência à mulher climatérica: novos paradigmas. Rev Bras Enferm. Brasília, 2009 Mar-Abril; 62(2):287-93. doi: 10.1590/S003471672013000400001

16. Fernandes CE, Baracat EC, Lima GR. Climatério: manual de orientação. São Paulo: Ponto; 2004. Available from: http:// professor.ucg.br/SiteDocente/admin/arquivosUpload/13162/ material/climaterio120-20Febrasgo202005.pdf.

17. Souza LS, Aldrighi JM. Sono e climatério. Repro. Clim. 2001; 16:20-25. doi: 10.1016

18. Pedro AO, Pinto-Neto AM, Costa-Paiva LHS, Osis MJD, Hardy EE. Síndrome do Climatério: inquérito populacional domiciliar em Campinas, SP. Rev Saúde Pública. 2003; 37(6): 735-42. doi: 10.1590/S0034-89102013000100001

19. Valença CN, Germano RM. Concepções de mulheres sobre menopausa e Climatério. Rev RENE. Fortaleza, 2010 Jan-Mar; 11(1): 161-71.

20. Vigeta SMG. Alterações do sono e menopausa: uma revisão da literatura. Cienc Cuid Saúde, 2007 Jul-Set; 6(3): 377-83. doi: 10.4025

21. Nievas $A F$, Furegato $A R F$, lannetta $O$, Santos JLF. Depressão no Climatério: indicadores biopsicossociais. J Bras Psiquiatr. 2006; 55(4): 274-9. doi: 10.1590/S0047-20852013000200001
Vol. 8 No. 141 doi: $10.3823 / 1740$

\section{Comment on this article:}

\section{(f) [B] in $8+\mathbf{S}$ P}

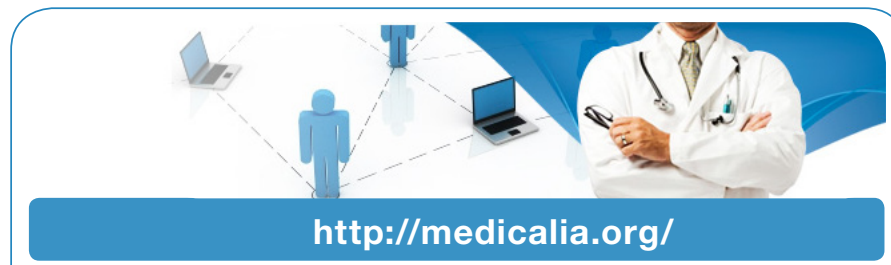

Where Doctors exchange clinical experiences, review their cases and share clinical knowledge. You can also access lots of medical publications for free. Join Now!

\section{Publish with iMedPub}

http://www.imed.pub

International Archives of Medicine is an open access journal publishing articles encompassing all aspects of medical science and clinical practice. IAM is considered a megajournal with independent sections on all areas of medicine. IAM is a really international journal with authors and board members from all around the world. The journal is widely indexed and classified Q1 in category Medicine. 